\title{
Characterization of middle Eocene tide-influenced delta: A study from core samples of Hazad Member, Ankleshwar Formation, South Cambay Basin, India
}

\author{
SAPAna JAiswal ${ }^{1}$ and Biplab Bhattacharya ${ }^{2, *}$ \\ ${ }^{1}$ KDMIPE, Oil and Natural Gas Corporation Limited, 9, Kaulagarh Road, Dehradun 248 195, India. \\ ${ }^{2}$ Department of Earth Sciences, Indian Institute of Technology, Roorkee 247 667, India. \\ *Corresponding author.e-mail: bbgeofes@iitr.ac.in; bb.geol.dgc@gmail.com
}

MS received 25 August 2017; revised 18 October 2017; accepted 10 November 2017; published online 25 June 2018

The Hazad Member (Middle Eocene) of the Ankleswar Formation in Cambay Basin, India, is traditionally reported as deltaic system. Present work documents three major facies associations, namely, (i) sandstone-rich upper delta plain (FA-1) deposits, (ii) sandstone-mudstone heterolithic lower delta plain-delta front (FA-2) deposits, and (iii) shale-dominated prodelta (FA-3) deposits, in an overall coarsening-up to fining-up succession. Tidalites are well preserved in FA-2 and are represented by laterally accreted tidal bundles, tidal beddings and vertically accreted tidal rhythmites, described from drill core samples in this communication. Laterally accreted tidal bundles with reactivation surfaces in sanddominated heterolithic units indicate time-velocity asymmetry in subtidal condition. Tidal beddings and tidal rhythmites in mud-dominated heterolithic units, associated with asymmetric/symmetric ripple forms and desiccation cracks, indicate periodic subaerial emergence in intertidal flat depositional setting. Systematic analysis of the architecture of the tidalites in different parts of the basin signifies rapid shift in sedimentation from subtidal to intertidal flat within the lower delta plain. Transitions from prodeltaic to tidally (subtidal-intertidal) affected delta front to lower delta plain and fluvial-dominated upper delta plain depositional systems attest to high frequency transgressive-regressive cycles in response to changing accommodation, as a result of sea level fluctuations and basinal tectonisms in the Cambay Basin.

Keywords. Tidal bundles; delta plain; facies associations; Hazad Member; Cambay Basin; Eocene.

\section{Introduction}

Sedimentary successions that exhibit a tidal signature are generally termed as 'tidalites' (Klein 1998; Kvale 2012), commonly represented by mudrich and sand-rich thin heterolithic strata (lenticular, wavy or mud-flaser bedding) to sandrich unidirectional, bidirectional (herringbone) or bundled cross-stratifications (Coughenour et al. 2009). Repetitive tidal signatures developed in very thin strata in a wide range of tide-dominated systems are known as tidal rhythmites (Greb and
Archer 1995). Tidal rhythmites are considered as the exclusive signatures of vertically accreted tidal facies originated in intertidal to subtidal systems in marginal marine depositional realm (Williams 1989; Dalrymple et al. 1991; Greb and Archer 1995; Mazumder and Arima 2005; Fan 2013; Bhattacharya and Banerjee 2015), where accommodation space creation is secured under relatively sheltered conditions.

Literature depicting characterization of tidalites and deciphering tidal flats from ancient and modern settings are plenty (Reineck 1972; Allen 1981; 
Archer et al. 1994, 1995; Greb and Archer 1995; Kvale and Matarlerz 1998; Eriksson and Simpson 2000; Mazumder 2004; Bhattacharya et al. 2012, 2015; Fan 2013 and many others). These studies are primarily dependent on field based observations, either from exposed rock sections or from recent tidal flats and estuaries. However, identification of the tidalites from drill core samples is always problematic due to:

(i) small size of preserved features,

(ii) quick change in orientation of primary structures due to cylindrical shape of the cores,

(iii) incomplete and poor preservation of larger tidal features, e.g., herringbone cross-strata, and

(iv) gaps in data due to the intermediate spaces between two adjacent drill cores, representing discontinuous record of the tidal features.

Keeping these constraints in consideration, the present paper attempts to characterize tidally generated sedimentary features as tidalites from drill core samples of the Middle Eocene Hazad Member, Cambay Basin, Gujarat, India. The present study is confined to Gandhar-Jambusar area of the Jambusar-Broach Block of the South Cambay Basin between Mahi River in north and Narmada River in the south (figure 1). It covers the area south of Gandhar, which includes Aliabet, Vagra, Pakhajan, Dahej wells in the south, Kangam, Uber wells in the north, and Samni, Khandali, Matar and North Sarban wells in the east.

So far, the Hazad Member (dominantly 13 sandstone units, designated as GS-0 to GS-12) has been interpreted as prograding deltaic depositional systems with development of tidal flats near the top (Pande et al. 1989; Aswal et al. 2013). These sediments were carried out by protoDadhar/proto-Narmada river systems from the east and northeast direction as interpreted from the sand thickness maps prepared by earlier workers (Parakh et al. 2013). However, these studies were not substantiated with adequate supportive facies analysis and other traditional sedimentological attributes. Despite that, these lithounits have been explored and exploited as important hydrocarbon reservoir since decades by ONGC. Thus, a detailed and systematic analysis of the Hazad Member was felt necessary. This paper provides first systematic documentation of the facies types to establish the depositional environment of the Hazad Member, with particular emphasis on evidences of tidal sedimentation.
Identification of the tidal signatures from core samples provides additional value to this study. Such systematic documentation will signify the extent of marine incursions in the Cambay Basin during the Middle Eocene time, which will provide important clues to characterize the hydrocarbon reservoirs in the Hazad Member in much better way.

\section{Geological background}

The Cambay Basin is a narrow elongated (NNWSSE) extensional basin located on western margin of the Indian Precambrian shield in the Gujarat state, between latitudes $21^{\circ}-25^{\circ} \mathrm{N}$ and longitudes $71^{\circ} 15^{\prime}-73^{\circ} 30^{\prime} \mathrm{E}$ (figure 1a). The entire Cambay Basin, extending from north of Sanchor to Gulf of Cambay, is about $425 \mathrm{~km}$ long and a progressively increasing width of $40 \mathrm{~km}$ in the north with an average width of $138 \mathrm{~km}$ in the middle part to over $100 \mathrm{~km}$ in the south. This Cenozoic extensional basin is a typical 'intracratonic aborted rift', which evolved due to separation of India from Seychelles at the end of the Cretaceous (Nortan and Sclater 1979; Biswas 1982; Kundu et al. 1996). The generalised lithostratigraphy of the Cambay Basin is summarised in table 1.

The Cambay Basin is subdivided into five major tectonic blocks based on major basement faults. From North to South these blocks are named as: (a) Sanchor-Patan Block, (b) Mehsana-Ahmedabad Block and (c) Tarapur-Cambay Block, constituting the North Cambay Basin, and (d) JambusarBroach Block and (e) Narmada-Tapti Block, constituting the South Cambay Basin. Lithostratigraphically, North and South Cambay Basins are distinct as deposited by two different drainage system, i.e., north-south flowing Proto-Saraswati river system in North Cambay Basin and eastwest flowing Proto-Narmada/Proto-Dadhar river system in South Cambay Basin, separated by the Mahi River.

The Jambusar-Broach Block is characterized by some basin margin faults in the east and west with several NNE-SSW to N-S trending listric normal faults within the block, which controlled syn-rift subsidence and the depositional processes (Parakh et al. 2013). Earlier works on Hazad sands in Broach depression suggested sediment dispersal by east to west flowing river systems under moderately constructive lobate delta system 


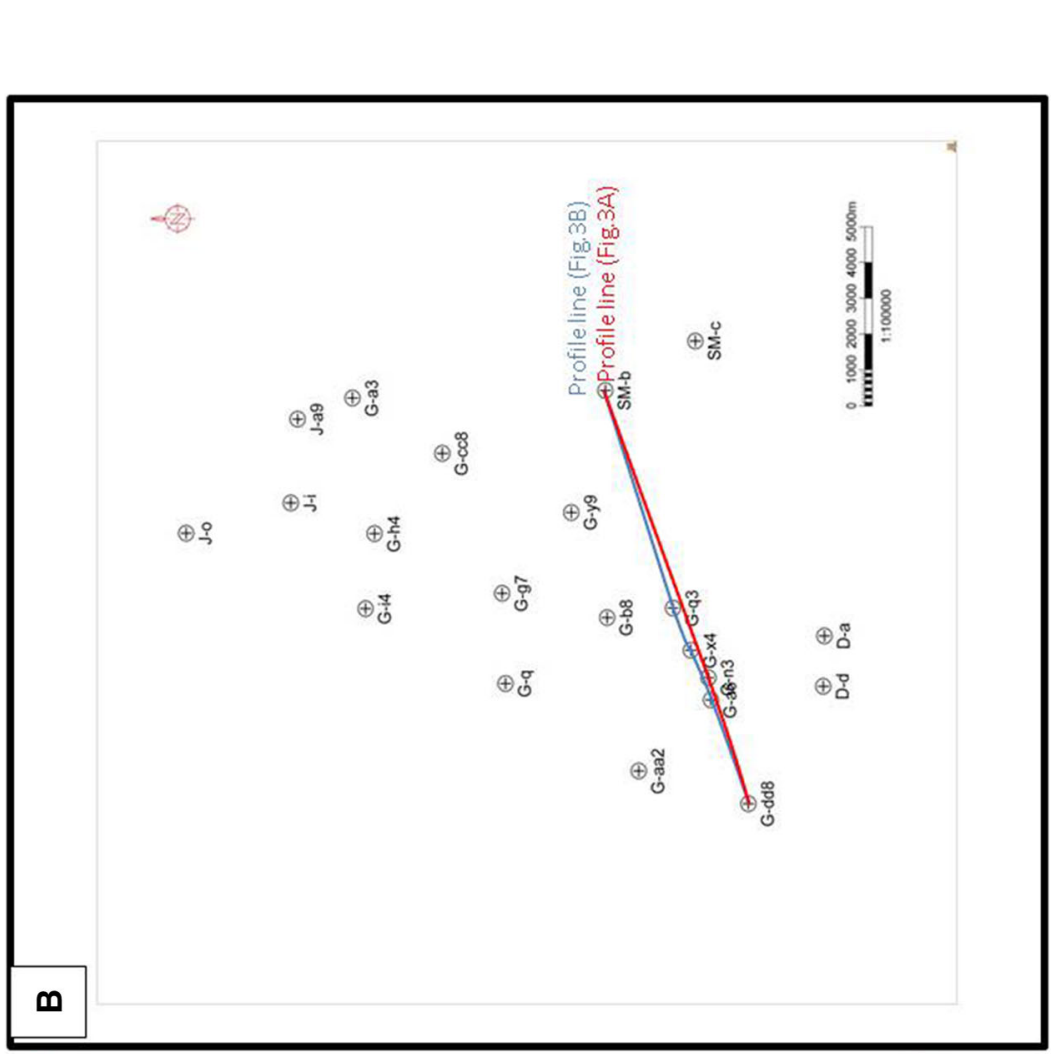

ฮี่
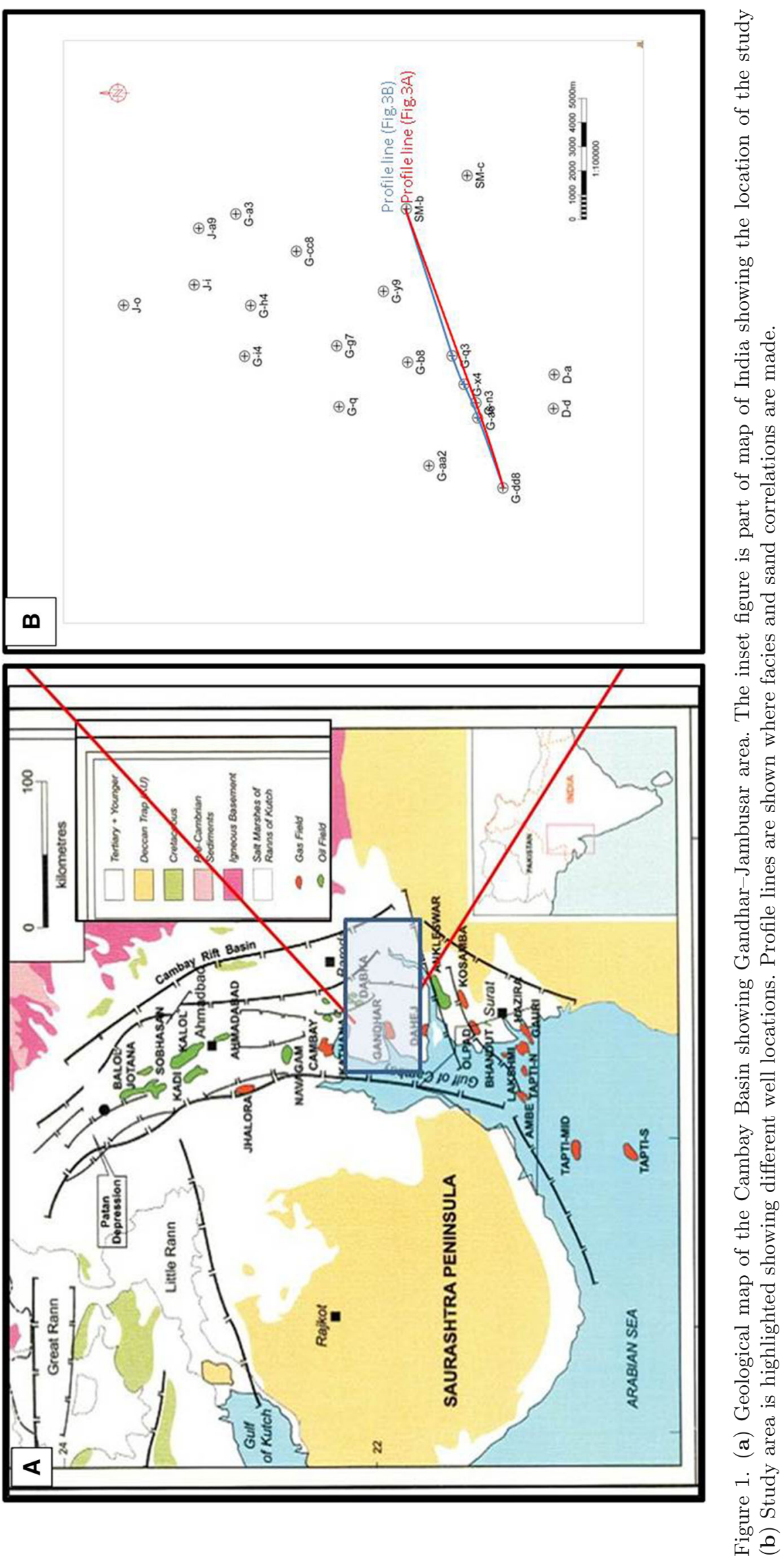
Table 1. Generalized lithostratigraphy of the Cambay Basin.

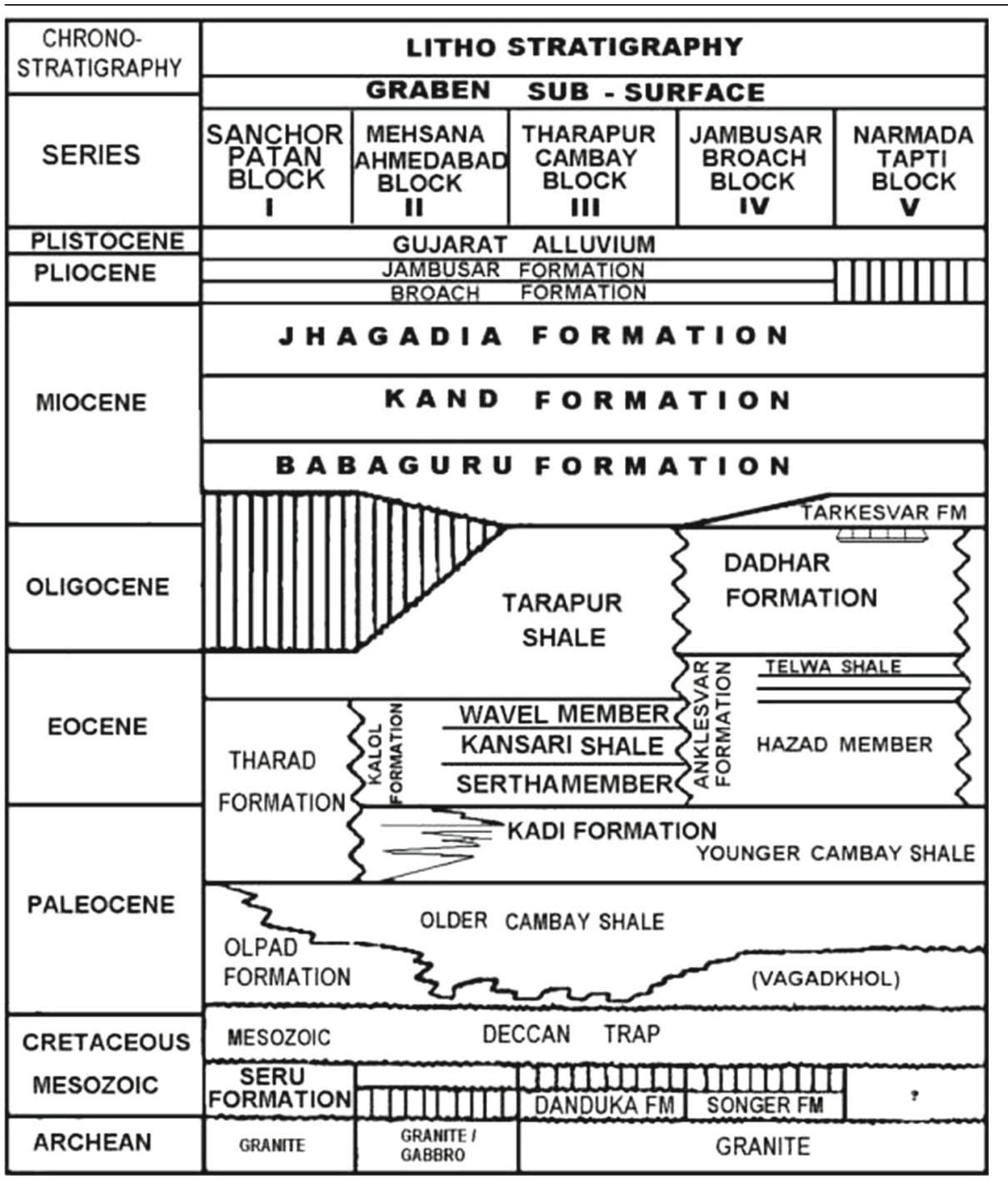

during Middle Eocene time. Sandstones within Hazad Member are bimodal, mineralogically mature and derived from acid igneous and high rank metamorphic source rocks (Mohan et al. 1990).

\section{Materials and methods}

This study on facies characteristics of the Hazad Member is mainly based on available conventional cores from different sandstone units of the Hazad Member. Across the oil fields of the Cambay Basin, sandstones within the Hazad Member are some of the most prolific producing horizons and thereby extensive conventional cores have been taken since the field was discovered. Each conventional core is of $5 \mathrm{~m}$ length with core diameter of $5^{\prime \prime}$, and is studied here in order to understand the facies characteristics and the depositional environment of the Hazad Member. More than $350 \mathrm{~m}$ of cores (representing 70 cores from 25 wells) from different sandstone units of the Hazad Member (average thickness $220 \mathrm{~m}$ ) were studied in detail at the Regional Geological Laboratory, ONGC, Vadodara. The cores have been studied in terms of its facies characteristics, megascopic and petrographic analysis to have a clear understanding on the process related facies analysis. Facies types are classified based on lithology, sedimentary structures, sediment body geometry and association (Miall 1980; Walker 1984; Reading 1996). Megascopic and thin section petrographic studies were carried out to identify and infer microfacies, mineral association and type of matrix/cement. Basic electrolog data incorporating gamma-ray (GR), 
Resistivity, neutron and density logs have been calibrated with facies characteristics from core lithology and the electrolog motifs were used for facies correlation where core is not available. The correlations of electrolog motifs were made in the sections parallel to the depositional dip (two such sections are shown in figures $1 \mathrm{~b}, 2 \mathrm{a}$ and $\mathrm{b}$ ) to know the facies changes and lateral variations in individual sandstone units.

\section{Sedimentology of the area}

Hazad Member consists of a number of sandstone units separated by intervening marine shales. The sandstone is mainly quartz arenitic in composition, and it generally thins and splits basinward (westward), intertonguing with the coeval Younger Cambay Shale. In the study area, the 220-m thick Hazad Member consists of thirteen stacked sandstone units of largely similar character (figure 2a and b). Eastward or landward, the sandstone becomes progressively well sorted and the intervening shales thin out or disappear, so that the successive units are amalgamated (figure 2b). Each sandstone unit exhibits superposition of three distinct facies associations, which in the following are presented stratigraphically from bottom to top.

Detailed sedimentological study of the subsurface cores were carried out and integrated with electrologs to have a process response depositional model of the Hazad Member and to understand its extension due west. The generalized overview of the overall lithofacies and textural characteristics of all the lithounits are described here. The overall sedimentary facies architecture bears signatures of deposition in a tide affected delta with profound bioturbation (Abbasi et al. 1992; Aswal et al. 2013). The lithofacies and their association indicate sedimentation took place in laterally adjacent depositional settings, commonly identified in three major facies associations, viz., sandstonerich facies association (FA-1), sandstone-mudstone heterolithic facies association (FA-2) and shaledominated facies association (FA-3) (see table 2). Three representative sedimentary logs showing distribution of different facies types from west (basinward) to east (landward) within the study area are presented in figure $2(\mathrm{a})$.

The sandstone-rich facies association (FA-1) consists of three facies, viz., massive poorly sorted sandstone (1a), medium to large cross-stratified sandstone (1b) and normally graded sandstone (1c) (figure 3a-d), predominantly occurring in lower part of the succession. The facies association forms coarsening-up parasequences and occurs at the middle and upper part of the successions in the central and eastern part of the basin, respectively. Petrographically sandstone is represented by poorly sorted coarse grained quartz arenite made up of sub-angular to sub-rounded, mainly monocrystalline quartz grains with carbonaceous clay matrix (figure 3e). The grain contacts are mostly line and point contact. Rarely, a few grains of chalcedony, microcrystalline chert and small patches of calcareous matter have also been noticed. On the whole, there is an increase in the matrix percentage in the lower part of the sand and laterally the matrix percentage increases towards east and north east. Overall facies architecture with intimate association of these three facies types suggests a fluvial depositional system.

The sandstone-mudstone heterolithic facies association (FA-2) consists of shale with sand lenticles (2a), coarsening- to fining-up sandstone $(2 \mathrm{~b})$, argillaceous sandstone (2c) and sandstoneshale heterolith $(2 \mathrm{~d})$ (figure $4 \mathrm{a}-\mathrm{d})$. All the facies types show varied sand:mud ratio with systematic change from sand to mud and mud to sand in vertical successions. Locally, bioturbation by Skolithos ichnofacies (figure 4e) is recorded in sandstones. Petrographically, the sandstone is represented by quartz arenites with bimodal grain size distribution (figure 4f). All the facies types are characterized by development of different tidallygenerated structures, like flaser, lenticular and wavy beddings, tidal bundles with quick sand-shale alternations, and abundant bioturbations, which indicates strong tidal influence within the lower delta plain depositional system. Detailed descriptions and interpretations of the tidalites are given in section 5. The sand-dominated facies signify deposition within the distributary channels, while the mud-dominated and heterolithic facies indicate deposition in intertidal-subtidal flats within the inter-distributary bays/plains (Reading 1996) (figure 4a). Distributaries are represented by meandering fluvial channels, but are commonly characterized by finer grained argillaceous sandstone representing low-energy end of the spectrum (meandering to straight/anastomosing) (Saha et al. 2016). Inter-distributary areas commonly change from freshwater through brackish to saline environments in a downdip direction (e.g., transition from swamps to marshes). Delta plain distributaries are usually characterized by narrow natural 

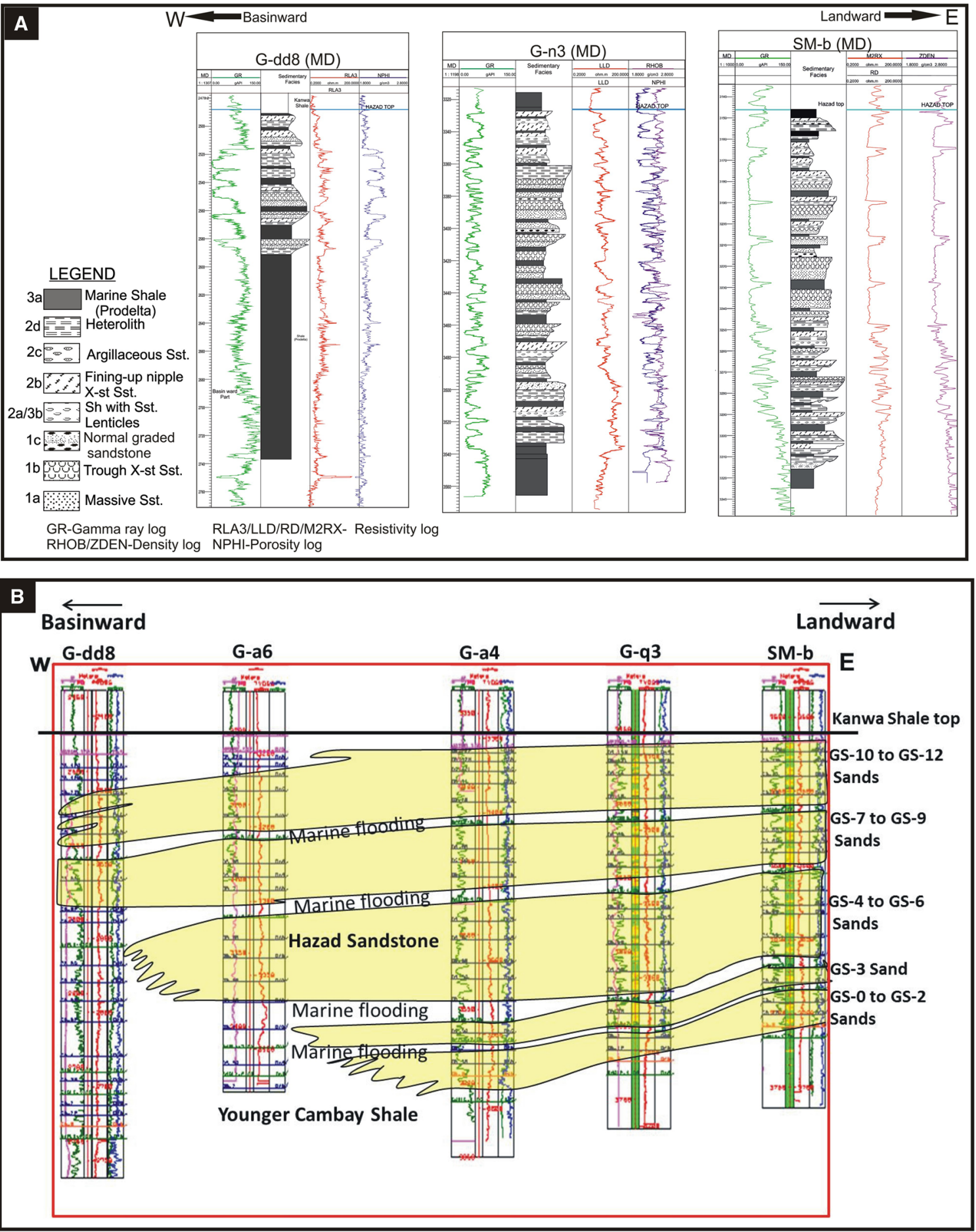

Figure 2. (a) Vertical and lateral distribution of three different facies associations in the Hazad Member resting on younger Cambay Shale in a depositional dip parallel section from basin margin to basin interior. Note recurrence of deeper facies in basin margin indicating events of marine flooding and basinward shift of facies associations indicating progradation. Vertical lines indicate locations where stratigraphic sections were made. Vertical scale is represented by measured depth (MD) in meters. (b) Correlation of different sandstone units within Hazad Member (GS-0 to GS-12) from basin margin to interior. Note the westward progradation of sandstone units, separated by events of marine flooding and stepped up contact between the younger Cambay Shale with overlying Hazad Member indicating punctuated progradation of sandstones. Also note the degree of progradation is maximum in the middle part of Hazad followed by a back stepping sandstone units (GS-9 to GS-12), indicating a rise of relative sea level. See text for details. 


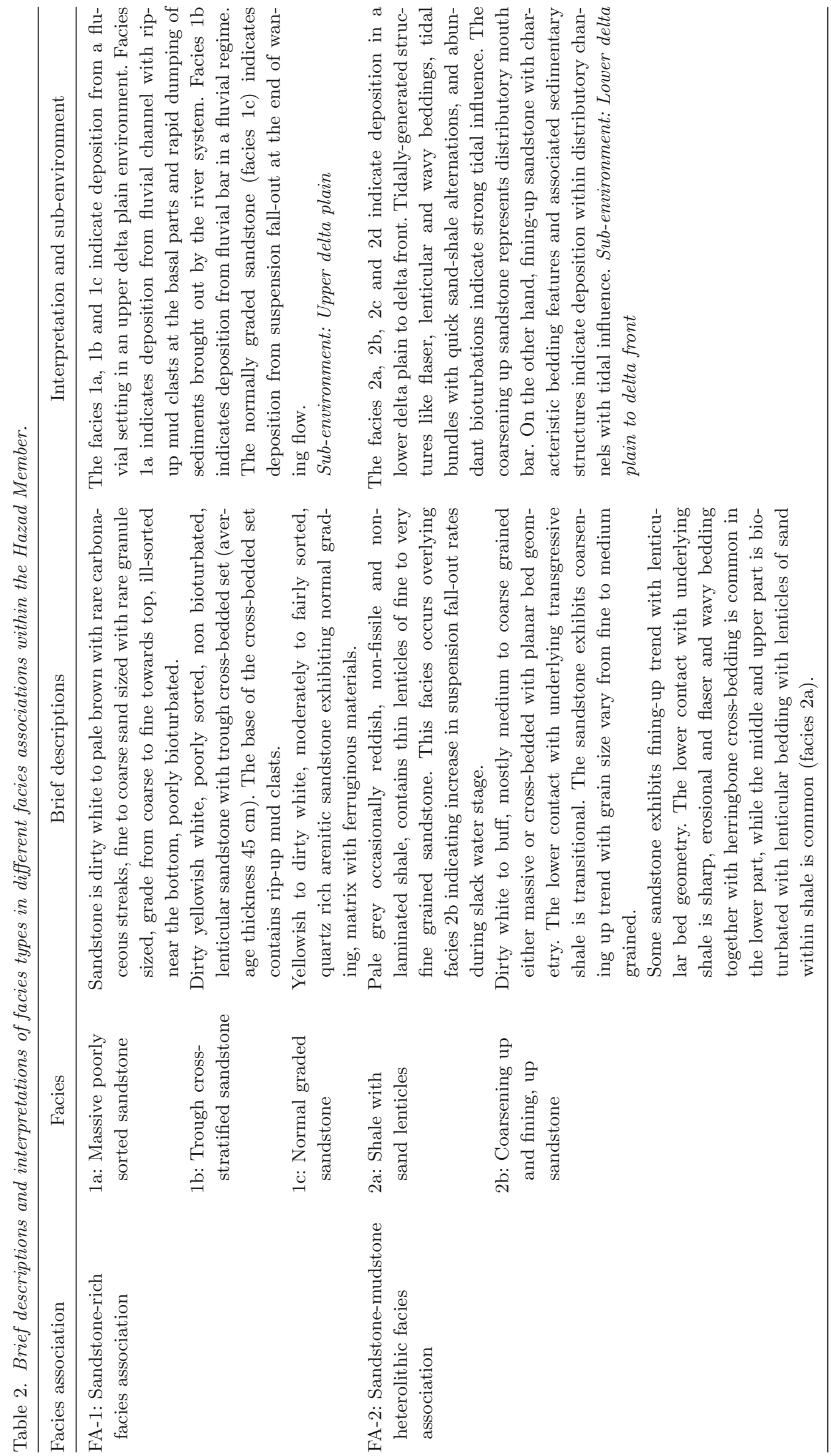




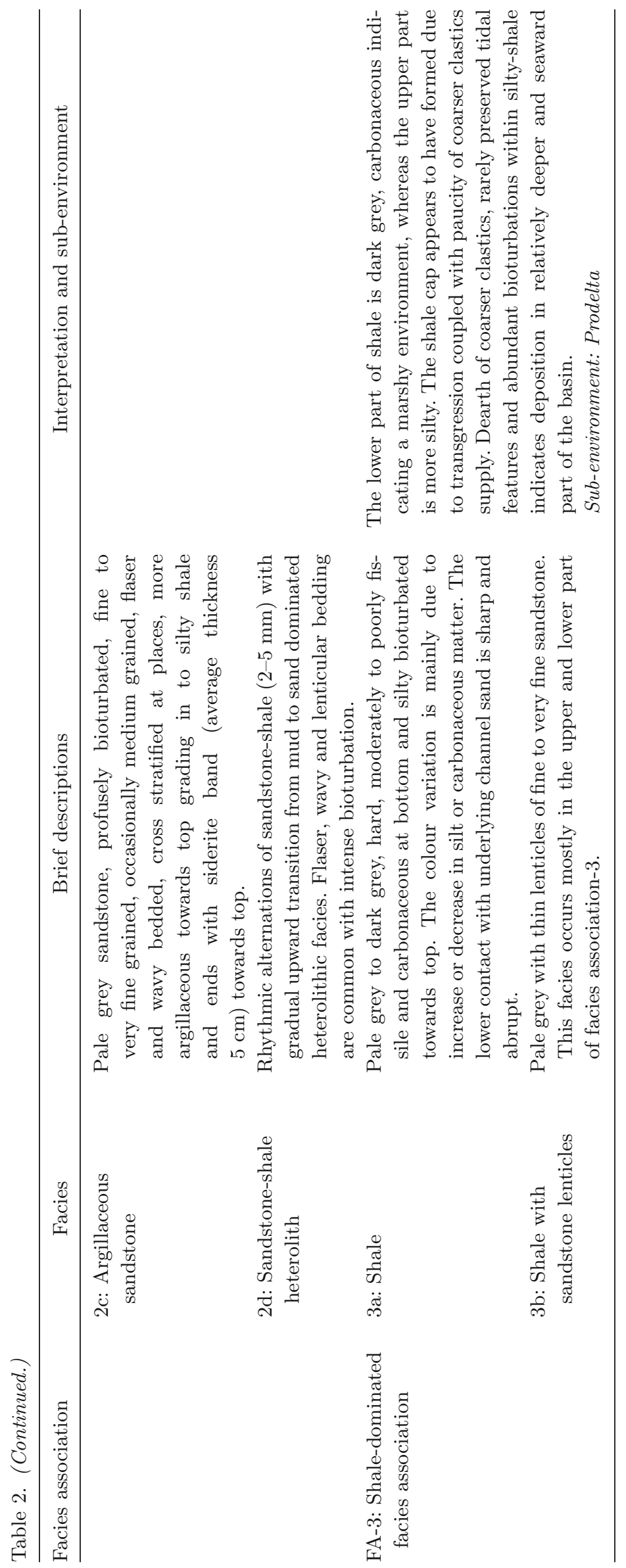



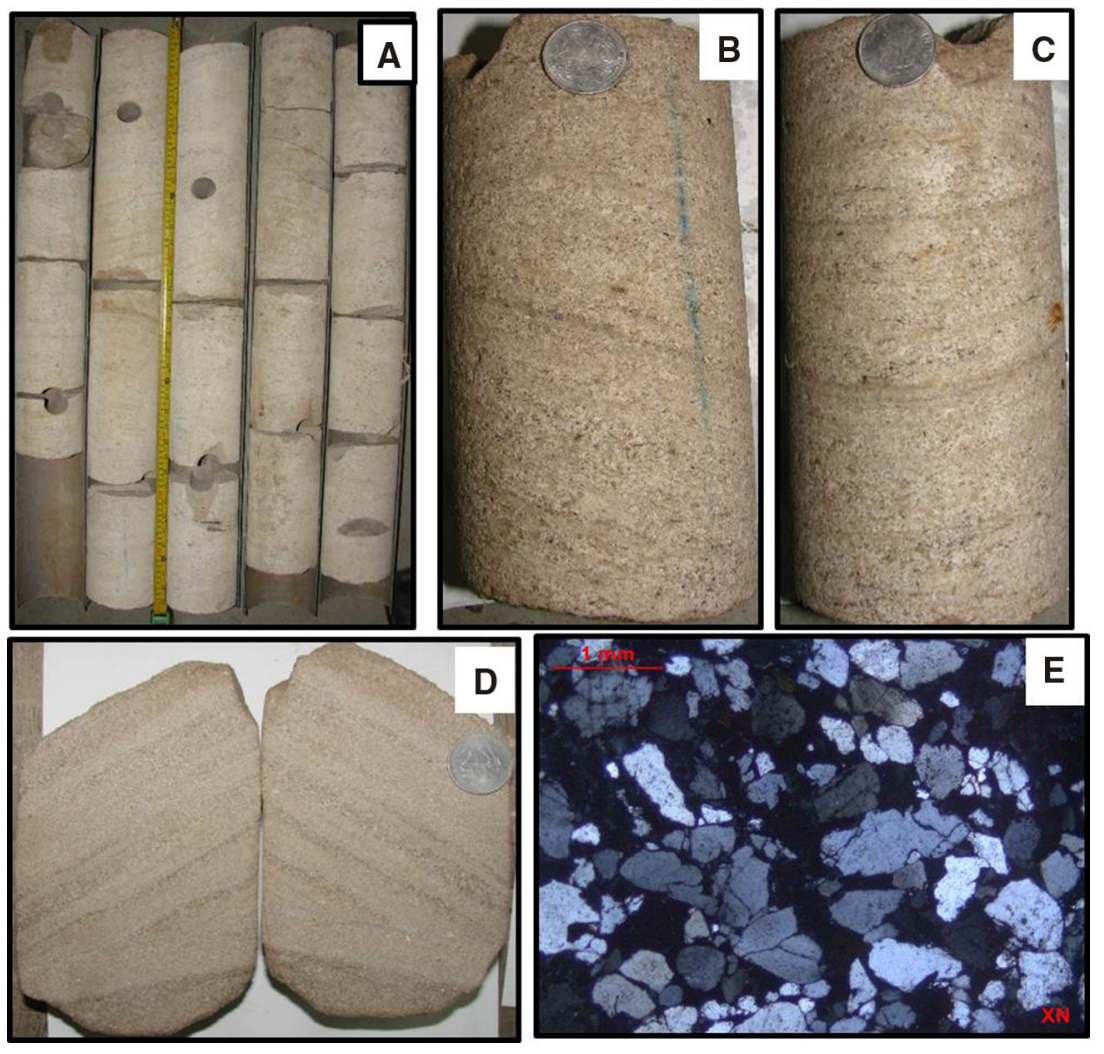

Figure 3. Core samples of facies association FA-1 showing (a) massive poorly sorted sandstone of facies-1a, (b), (c) and (d) coarse-grained poorly sorted cross-stratified sandstone, facies (1b). (e) Photomicrograph showing poorly sorted coarse grained quartz arenite with sub-angular to sub-rounded quartz-feldspar grains with carbonaceous clay matrix. Diameter of the coin is $2.5 \mathrm{~cm}$.

levees and numerous crevasse splays. Avulsion (i.e., delta-lobe switching) is frequent due to high subsidence rates, as well as rapid gradient reduction associated with channel progradation.

The shale-dominated facies association (FA-3) is represented by grey, carbonaceous shale (3a) and shale with sand lenticles (3b) (figures $5 \mathrm{a}$ and $\mathrm{b}$ ). Dearth of coarser clastics, rarely preserved tidal features and abundant bioturbations within siltyshale indicates deposition in relatively deeper and seaward part of the basin. Overall facies character with predominance of grey, carbonaceous shale and sand lenticles in the upper part signify a prodelta depositional setup.

Thus, the lithofacies and their association indicate sedimentation took place in laterally adjacent sub-environments, viz., upper delta plain, lower delta plain/delta front and prodelta. The overall coarsening-up successions with profound evidences of bioturbation in fluvial-tidal interactive system suggest deposition in a tide-affected deltaic environment. In such deltaic setup, the sandstonerich facies association (FA-1) consisting of massive poorly sorted sandstone and cross-stratified sandstone without any bioturbation and the normal graded sandstone represents the fluvial upper delta plains (figure $4 \mathrm{~b}$ ). The poorly sorted medium to large scale cross stratified sandstone possibly indicates deposition of bar in a fluvial regime. The poorly sorted massive sandstone indicates rapid deposition from fluvial channel. The normally graded sandstone indicates deposition from suspension fall-out at the end of waning flow.

The facies association (FA-2) consisting of shale with sandstone lenticles (2a), coarsening-up and fining-up sandstone $(2 \mathrm{~b})$, argillaceous sandstone (2c) and sandstone-shale heterolithic facies (2d) indicate deposition in a lower delta plain to delta front setting. Strong tidal influence is evident in the presence of tidally-generated structures like flaser, lenticular and wavy beddings, tidal bundles and profuse bioturbations with Skolithos type of ichnofabric (figures 4b-e). The ichnofacies contains predominantly deeply penetrating vertical and cylindrical burrows produced by suspension feeders. Horizontal structures and structures produced by mobile organisms are absent. The Skolithos ichnofacies indicates the presence of 

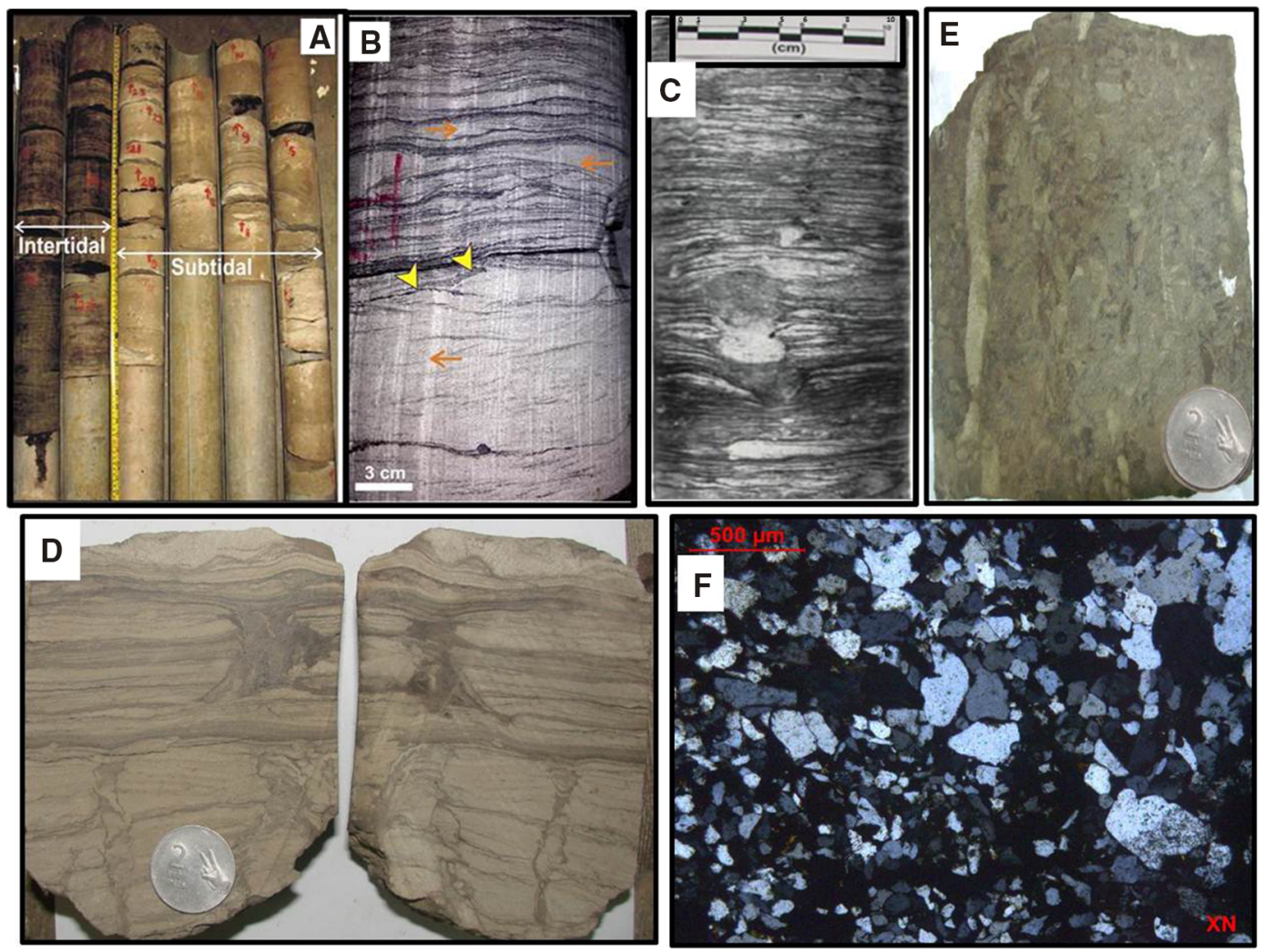

Figure 4. (a) Sand-dominated lithounits of subtidal origin and sand-mud rich heterolithic units of intertidal origin. (b) Sandstone-mudstone heterolithic unit with sand-dominated units near bottom part and mud-rich units in the upper part (facies 2d). Climbing ripple cross-strata (yellow small arrows) are common. Apparent bidirectionality of low angle foresets laminae as indicated by laterally accreted tidal bundles, is marked by orange arrows. Wavy bedding is present in the upper part. (c) Sandstone-mudstone heterolithic unit showing flaser and lenticular bedding. (d) Bioturbated heterolithic unit with frequent vertical burrows. (e) Skolithos ichnofabric with deeply penetrating, straight walled vertical burrows. Diameter of the coin is $2.5 \mathrm{~cm}$. (f) Photomicrograph showing medium to fine grained sub-angular sub-rounded quartz arenite with apparent bimodality of grain size indicating tidal deposition.
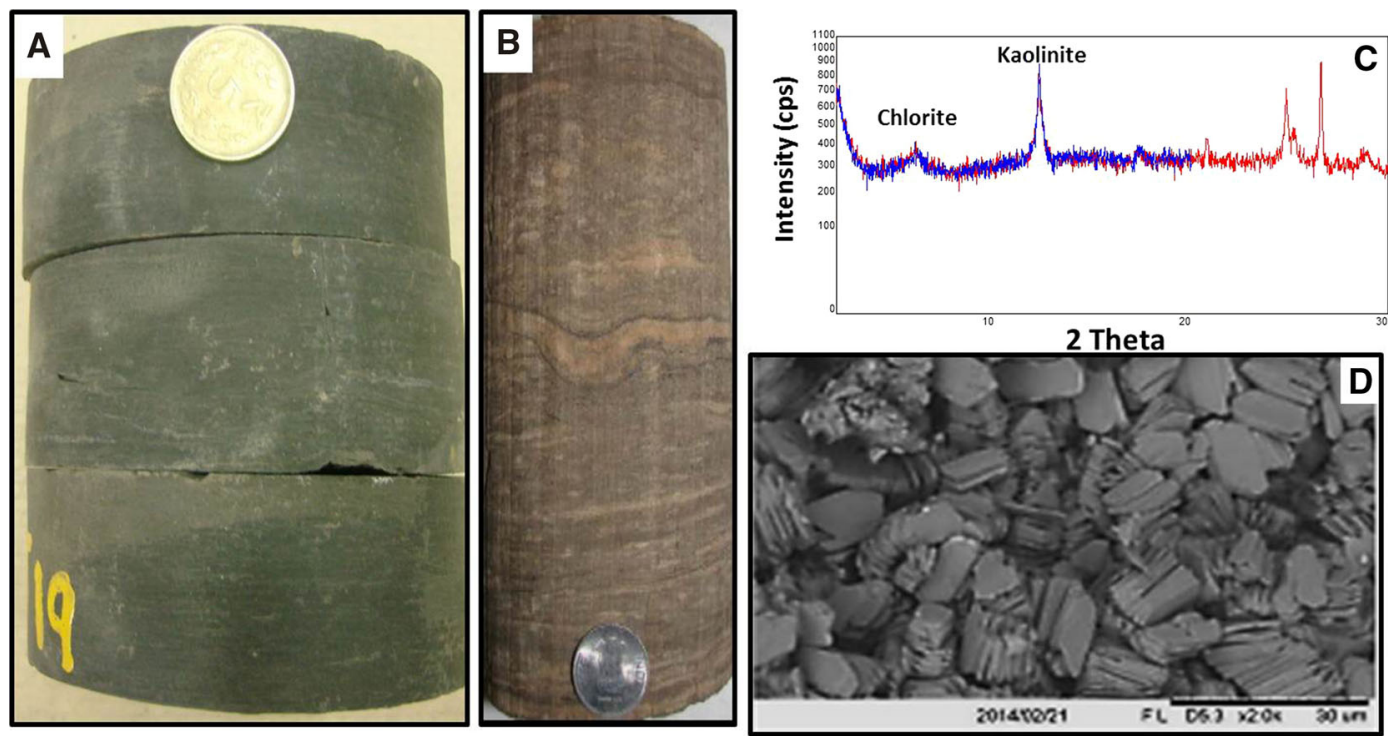

Figure 5. (a) Dark grey to black carbonaceous shale, facies (3a) of facies association FA-3. (b) Shale with sand lenticles, facies 3b. (c) XRD analysis showing clay mineralogy (chlorite and kaolinite), red curve indicates glycolated sample. (d) SEM photomicrograph showing booklets of pore filling kaolinites. Diameter of the coins are $2.2 \mathrm{~cm}$ (figure $5 \mathrm{a}$ ) and $2.5 \mathrm{~cm}$ (figure $5 \mathrm{~b}$ ), respectively. 
well-sorted, non-cohesive sand in shallow marine environments with strong waves or currents, characterized by frequent reworking and rapid changes in the rate of sedimentation. Also, tidally affected flaser, wavy, lenticular bedding in moderate to poorly sorted sandstone in the lower part of facies succession favours slow sedimentation rate during initial phase of bar development. The coarsening up sandstone possibly represents distributary mouth bar in a lower delta plain regime. On the other hand, fining-up sandstone with associated sedimentary structures indicate deposition within choked distributary channels with tidal influence in delta-front region. Mutually opposite bidirectional cross-bedding (figure 4b), as observed in cores, is caused due to flood-ebb currents in the distributary channel. The upper contact of this channel sandstone is transitional with argillaceous and silty sandstone (2c) grading into silty shale.

The shale-dominated facies association (FA-3) (figure 5a and b) with dark grey colour and carbonaceous nature indicates an euxinic marshy environment, whereas the upper part is more silty. The shale cap appears to have formed due to marine flooding coupled with paucity of coarser clastics supply.

The XRD analysis of core samples revealed presence of chlorite and kaolinite as dominant clay minerals (figure 5c). The SEM analysis depicts the presence of grain coating chlorite and pore filling kaolinite (figure 5d), which can be described as this sandstone was deposited in a relatively shallow deltaic environment as part of a large fluvial system. Weathering of the rocks brought large amounts of particulate Fe to the river mouth. Abundant Fe- and Mg-rich materials were supplied during the deposition of distributary channel sediments in the delta front setting and mainly in alkaline conditions. An increase in salinity in the distributary channel complex caused Fe flocculation and deposition. With increasing burial depth, kaolinite tended to be transformed into chlorite. Grain-coating and pore-filling chlorite occurs early, predating the development of secondary porosity and the precipitation of quartz overgrowths and Fe-poor calcite.

\section{Evidences of tidal influence}

Earlier works on Hazad Member reported signatures of tidal flat based on indirect evidences like increasing ratio of argillites, occurrence of coal, intense biotrubation, etc. (Aswal et al. 2013).
In this paper, we studied and documented direct evidences of tidal sedimentation, as observed in 70 numbers of core samples, having average thickness of $5 \mathrm{~m}$ each.

Spatial and temporal variations in different flow types in the tidal environments have produced distinct sedimentary structures in the studied rock succession. The most conclusive of these structures are: (a) tidal bundles with mud drapes on sand foresets (often double mud drapes) (figure 6a and b) tidal beddings (like flaser, lenticular and wavy beddings) (figure $6 \mathrm{~b}$ and $\mathrm{c}$ ), and (c) horizontally laminated tidal rhythmites (figure $6 \mathrm{~d}$ ). In addition, other structures known to occur due to the periodic change of tidal current directions, viz., mutually opposite-oriented strata bundles, ripple forms in different orientations, etc. (figures $4 \mathrm{~b}$ and 6a) (e.g., Boersma 1969; Klein 1970; Visser 1980; Allen 1981; Boersma and Terwindt 1981; also see, Bhattacharya and Bhattacharya 2006; Bhattacharya et al. 2015). These tidalites are dominantly preserved within the facies types of the lower delta plain facies association (FA-2) within the Hazad succession. Detailed characteristics of different tidalites are described below.

\subsection{Tidal bundles}

Tidal bundles are characterized by a sand-mud couplet with varying thickness, commonly considered as depositional unit corresponding to one tidal cycle. The tidal bundles are separated into four components: (i) a sandstone lamina deposited during the dominant current stage; (ii) a mud drape formed during the subsequent slack-water stage; (iii) another sandstone lamina deposited during the subordinate current stage, commonly thinner than the previous sand deposited, and (4) a second muddrape formed during the slack water stage following the subordinate current stage (figure 6a).

Cross-stratified sandstones (in facies $2 \mathrm{~b}$ and $2 \mathrm{~d}$ ) are characterized by tidal bundles of various types. The studied cross-strata are characterized by laterally accreted sand foresets bounded by mud drapes. Thickness of the bundled foresets varies from few $\mathrm{mm}$ (densely spaced) to few $\mathrm{cm}$ (widely spaced) in between successive sets, depending on variation in grain sizes and thickness of the host sets. Locally, within thicker $(>6 \mathrm{~cm})$ well sorted medium to coarse sandstones, the bounding mud drapes tend to become thinner and sometimes too thin to be recognized, resulting in mud free bundled foresets. Tidal bundles are often associated 


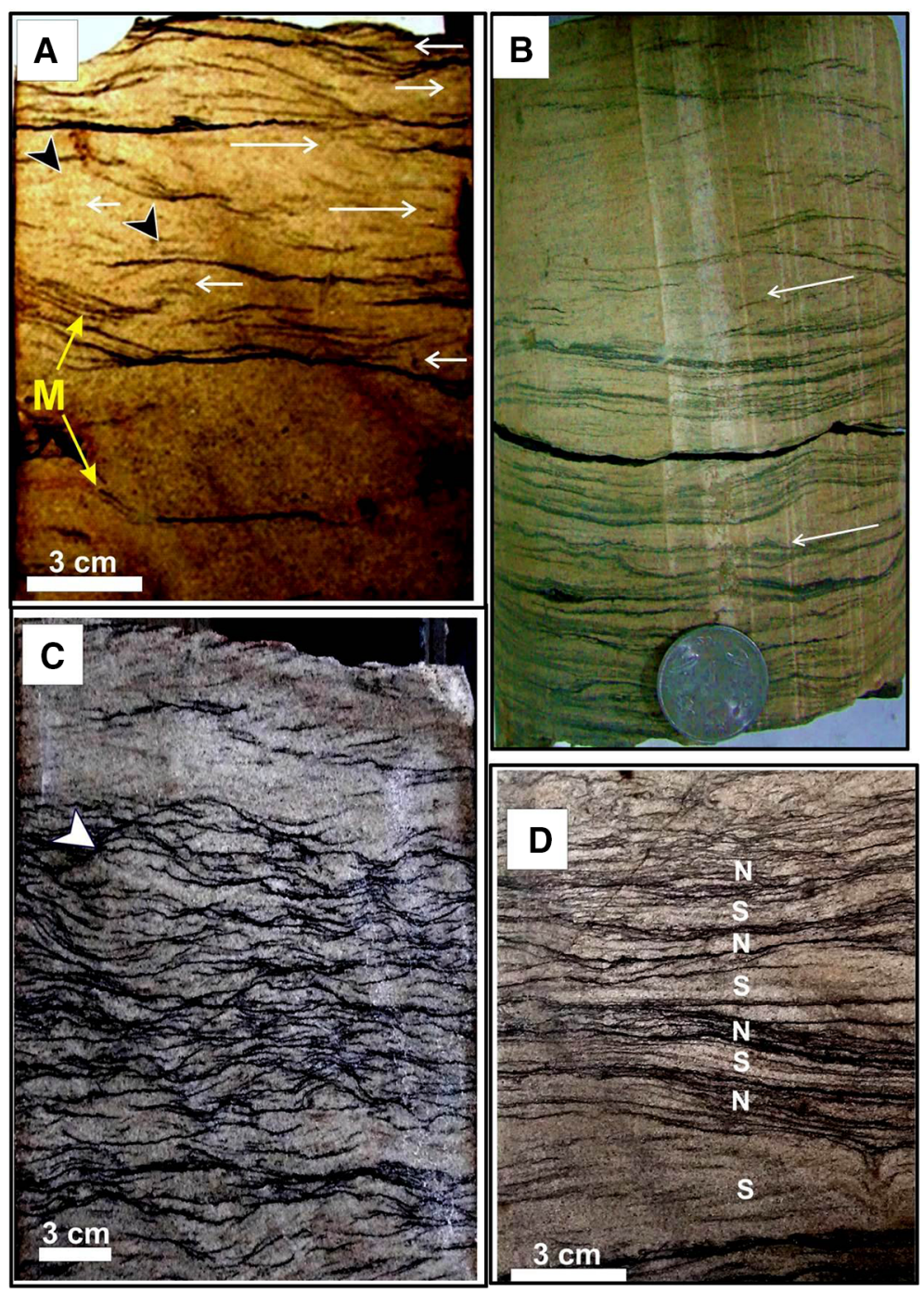

Figure 6. Polished core samples showing (a) Vertically stacked laterally-accreted tidal bundles in sand-dominated lithounits. Apparent bidirectionality of foresets in adjacent strata bundles are marked by white arrows. Climbing ripples (black arrow) and double mud drapes (M) are abundant. (b) Coarse-grained sandstone (facies $2 \mathrm{~b}$ ) showing low angle cross-strata, with mud drapes on foresets and reactivation surfaces within foresets marked by white arrows indicating changes in flow direction. (c) Flaser bedding in heterolithic units in lower-middle part, changing to sand-rich climbing ripples with laterally accreted tidal bundles. Locally preserved ripple forms show symmetrical rounded crests (white arrow). Lowest order reactivation surfaces are marked by yellow arrows within the climbing ripple laminated upper unit. (d) Tidal rhythmites represented by alternate sand-dominated and mud-dominated units, signifies spring (S)-neap (N) cyclicity. Diameter of the coin is $2.5 \mathrm{~cm}$.

with sigmoidal cross bedding of variable thickness, commonly bounded by densely laminated layer of very fine sand and/or mud within the sandstonerich facies succession. Sequential tidal bundles exhibit a very conspicuous thick-thin arrangement of laminae (figure 6d).

\subsection{Mud drapes}

In certain tidal bundles, it is common to find very fine mudstone closely interlaminated with very clean, well sorted sandstone. These two contrasting lithologies occur clearly and discretely with no mixing of materials. Where mud dominates, the sand occurs as thin laminae and lenses, whereas with a domination of sand the mud occurs as continuous or discontinuous laminae (figures 4b, 6a and b, 7a). In many cases, the mud occurs as draping layers over sand-ripple forms or on the foresets of cross-bedding within the sand. Mud-draped cross strata are result of alternating bedform migration during high flow velocities and suspension fall out of mud during the slack water phases between two successive tides (high and low). 

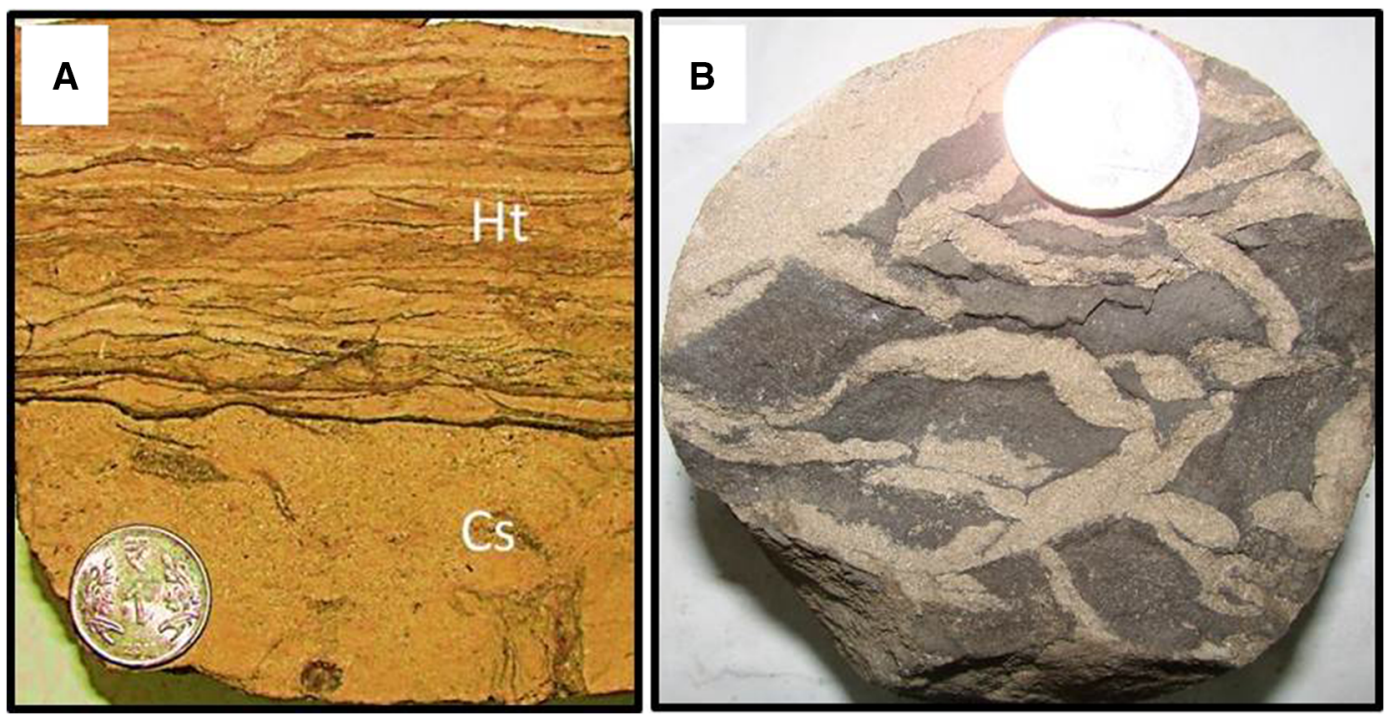

Figure 7. (a) Polished core sample showing cross-stratified sandstone (Cs) of facies 2b, overlain by thin heterolithic units $(\mathrm{Ht})$ of facies $2 \mathrm{~d}$. Note presence of mud-draped symmetrical ripple form at the top of Cs unit. Wavy and lenticular beddings are prominent in the Ht unit. (b) Sand filled desiccation cracks on mudstone bed surface. Diameter of the coin is $2.5 \mathrm{~cm}$.

\subsection{Flaser, lenticular and wavy bedding}

Alternate sand-dominant and mud-dominant units manifest spring-neap tidal cyclicity, with systematic development of flaser, wavy and lenticular beddings in an overall fining-up succession. The flaser beddings are characterized by simple, bifurcated and wavy flasers. Within the sandstone-dominated intervals, flaser bedding with discontinuous mud streaks is common. Sand/silt-shale laminae couplets occur in bundles within the heterolithic intervals, which are separated by persistent shale laminae. Lenticular beddings are characterized by connected or disconnected sand lenses embedded within mud. Flaser, wavy and lenticular beddings are identified as 'tidal beddings' following Fan (2013), with regular increase in mud content and decreasing grain size. Locally, the ripple forms preserved within flaser/wavy beddings show symmetrical, rounded crests similar to wave ripples (figures $6 \mathrm{c}$ and $7 \mathrm{a}$ ). Sand-filled desiccation cracks (figure $7 \mathrm{~b}$ ) are locally present within the muddominated heteroliths.

\subsection{Interpretations of tidalites}

Tidal bundles with double mud drapes (figure 6a) correspond to the sedimentation during dominant ebb and flood tide event (Boersma and Terwindt 1981), interrupted by two still stand phases corresponding to two mud drapes, respectively (Greb et al. 2011; Choi and Kim 2016).
Arrangement of successive mud-sand-mud laminae within sand-dominated units are conclusive evidence of subtidal environments (e.g., Nio et al. 1983; Dalrymple and Choi 2007). The difference in the thickness and number of sandy foresets enclosed between the two bounding mud layers is attributed to the sequential change in the strength of tidal current. The thickness of the bounding drape is controlled by the amount of mud in the system during the slack phase. The progressive thickening and thinning of sandy foresets signify neap-spring-neap tidal cycle (figure 6d) (e.g., Kvale 2006; also see, Bhattacharya and Banerjee 2015). The bidirectional strata bundles (figures $4 \mathrm{~b}$ and 6a) suggest reversal of tidal current, separated by pauses (Boersma and Terwindt 1981; Bhattacharya and Bhattacharya 2006). Systematic current reversals and thick-thin pair may form once a day in the diurnal and twice in the semidiurnal tidal regimes in modern environment (Allen 1981; Kvale 2006, 2012; Greb et al. 2011; Bhattacharya and Jha 2014).

The wave-reworked current ripples, mud drapes and tidal bundles aptly provide supportive evidence of their occurrence within a tide-dominated environment with minor wave influences (figure 8). Regular changes of flaser, wavy and lenticular bedding in an upward-fining succession, cyclical tidal rhythmites, in the fining-upward succession signify sedimentation in an intertidal flat setting (Fan 2013; Bhattacharya and Banerjee 2015). The intertidal flat has been subjected normal fair-weather 


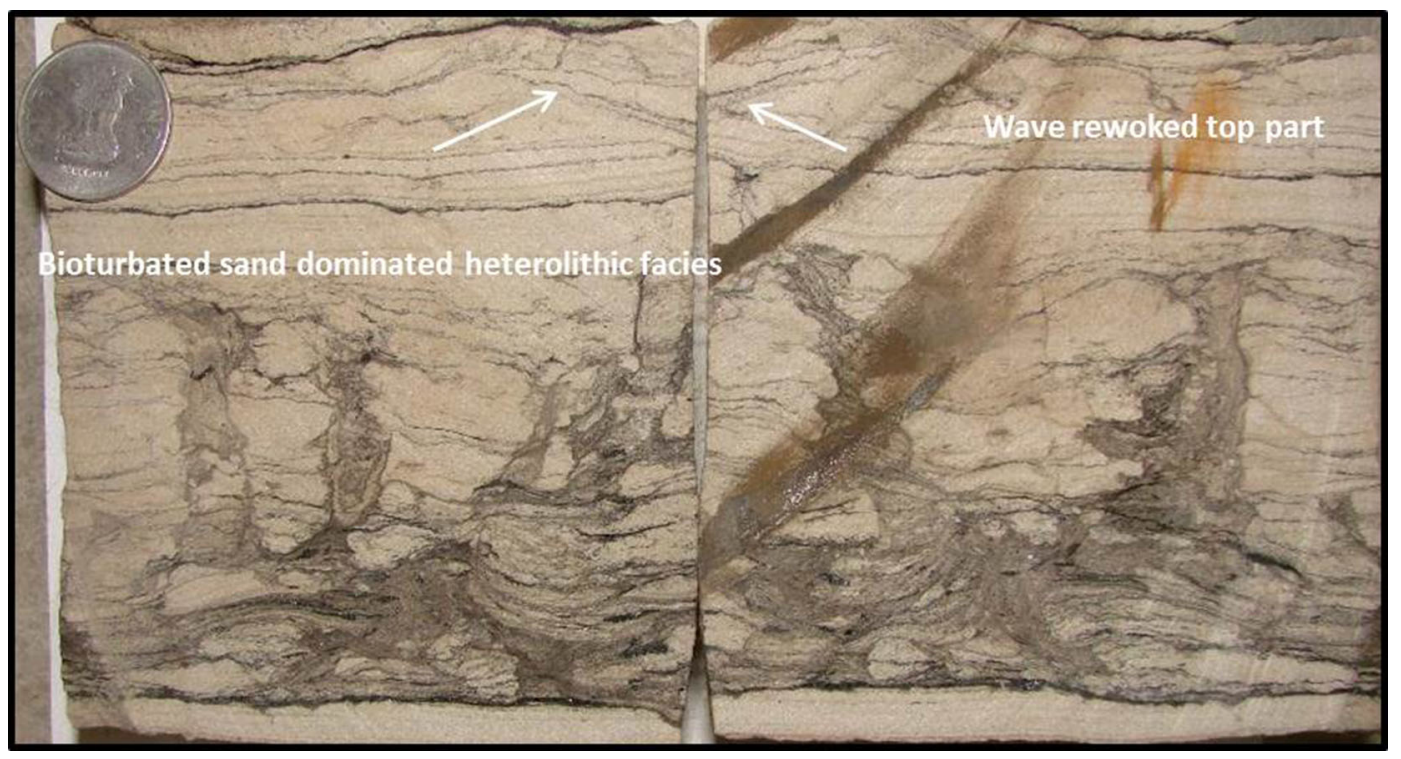

Figure 8. Polished core sample showing bioturbated sand-dominated heterolithic facies (2d), overlain by wave-reworked sandstone in top part. Note absence of bioturbations in the reworked sediments, symmetrical ripple form on top bed surface and wave reactivation surfaces (white arrows) marked by mud laminae within the wave ripple laminated top part. Diameter of the coin is $2.5 \mathrm{~cm}$.

reworking as a result of which, wave reworking (e.g., spill over of ripples) of tidalites may have taken place. Presence of wave-reworked ripples in certain beds suggests shallow water wave activity (figure 8) (Bhattacharya et al. 2012). Presence of desiccation cracks is indicative of periodic exposure of the intertidal flats during tidal slacks (figure $7 \mathrm{~b}$ ).

\section{Discussion}

Facies analysis from different conventional cores taken from Hazad Member of the South Cambay Basin revealed three laterally adjacent shore parallel facies associations, viz., the upper delta plain, the lower delta plain/delta front and the prodelta (Saha et al. 2016). Lateral and vertical facies correlation within the 13 different sandstone units of Hazad Member in depositional dip-parallel section (figure $2 b$ ) reveals cyclic changes in facies associations that signify changes in paleogeography. Each cycle within an individual sandstone unit starts with a relatively deeper water facies of delta frontlower delta plain, followed up by upper delta plain fluvial facies (figure 2a). The upward termination by the marine shales followed by younger sandstone unit indicates a rise in relative sea level and large-scale marine flooding. Thus, the lower part of the Hazad Member consists dominantly of lower delta plain/delta front facies associations followed up by upper delta plain facies association, indicating a shallowing up or coarsening up depositional pattern up to the middle part of Hazad Member (figure 2b). Facies correlation indicates a basinward shift of delta plain and delta front facies associations over the prodelta facies association. This is again followed by a landward shift of facies associations towards the top part of Hazad indicating a fining up trend. Vertical stacking of similar sandstone units indicates that the overall progradation of the Hazad sandstone units were punctuated and the maximum progradation attained during the middle part of Hazad Member (figure 2b). The lower delta plain facies associations are characterized by development of wide tidal flats. However, sediments transported by the fluvial system from landward part develops prograding delta by distributary channels within the broad intertidal to subtidal settings of the delta front (figure 9).

The facies correlation made from basin margin to basin interior (figure $2 \mathrm{~b}$ ) indicates dominant presence of fluvial facies association towards landward part. However, towards basin interior, Facies association 1 occurs at several levels in the middle and upper part of Hazad Member indicating progradation of the facies belt. The sandstone rich facies within the Hazad Member pinches out basinward indicating the seaward limit of progradation. The sediments, brought out by the river system, the Proto-Narmada and Proto-Mahi Rivers, were 


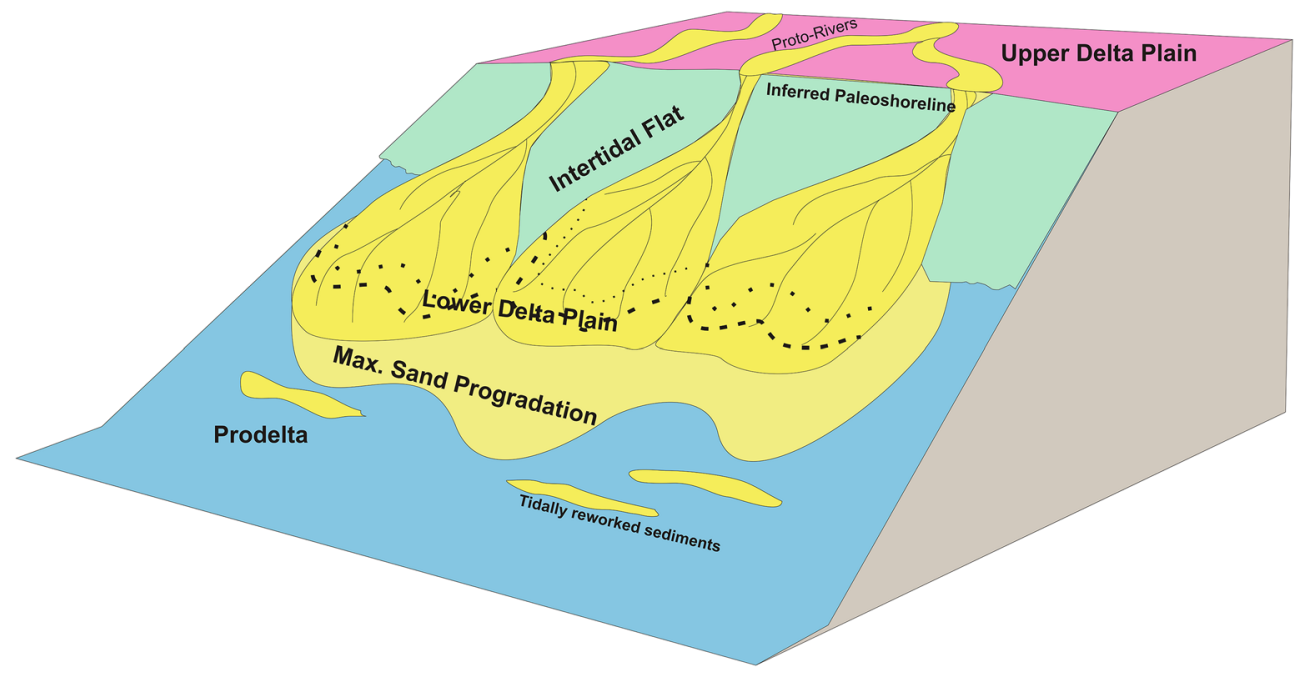

Figure 9. Schematic depositional model of the Hazad Member showing distribution of major subenvironments.

reworked by tidal processes. This may be due to the limited sand supply at the beginning of relative sea level fall. Eventually, the progradation of delta towards the middle of the Hazad Member indicates an increase in sediment supply.

The lower delta plain sediments record cyclic stacking of coarser and finer sedimentary facies successions, accumulated under two major depositional systems:

(a) Subtidal depositional system, characterized by sandstone-dominated facies succession (figures $4 \mathrm{~b}$ and $6 \mathrm{~b}$ ) with laterally accreted tidal bundles, commonly associated with frequent reactivation surfaces, bidirectionality of strata bundles (figure 6a) and relative dearth of mudstone with double mud drapes on sandstone foresets.

(b) Intertidal depositional system, represented by mudstone-rich heterolithic facies succession with smaller laterally accreted tidal bundles, abundant tidal beddings and vertically accreted tidal bundles (rhythmites) (figure 4b and 6d), frequently associated with wavereworked ripple forms and desiccation cracks (figure 7b).

Multiple cycles of subtidal-intertidal-subtidal deposits are documented, with predominance of subtidal deposits in the basinward side (west) and intertidal deposits in the landward side (east) (figure $2 \mathrm{a}$ and $\mathrm{b}$ ). Each such cycle comprises of one subtidal deposit overlain by an intertidal deposit, thus forming one complete tidal cycle with gradual shift in depositional condition from subtidal to intertidal settings (figure 4a). The architecture of the tidalites resembles graded fining-upward successions formed on modern tidal flats (Reineck and Singh 1980; Fan 2013). The true thickness of such graded cycles cannot be determined due to lack of preservation of continuous core samples. The lamina thickness versus frequency calculation cannot also be attempted due to the same problem. So, in this communication we restrain ourselves from making any comment on the tidal range or tidal cyclicities for the studied succession.

As a whole, the coarsening-up to fining-up sedimentary succession of the Hazad Member in the Cambay basin, with progradational deltaic lobes in the lower part followed up by predominant tidal sedimentary succession in the upper part, signifies a regressive to transgressive shift of the shoreline. Such encroachment of the sea towards land evident in the top part of Hazad is caused by significant change in the base level and accommodation in response to change in sea level and/or basinal tectonisms (subsidence).

\section{Conclusions}

This paper systematically documents tidalites from the Middle Eocene Hazad Member for the first time, and highlights important aspects of tide-led sedimentation in the Cambay Basin. This study is unique as the documentation of the tidalites is made from drill core samples only, which is rarely attempted. Followings are the significant findings and conclusions: 
- Facies succession bearing various tidalites (tidal bundles, tidal beddings and tidal rhythmites) signifies sedimentation in a subtidal to intertidal depositional system, with rapid fluctuation in depositional conditions.

- Facies architecture reveals predominance of prodeltaic sediments in the western part, delta front to lower delta plain with abundant tidalites in the central part and fluvially-dominated upper delta plain deposits in the eastern part, signifying basinward progradation of the facies succession.

- Overall coarsening-up succession in the lower part followed by fining-up successions at the upper part of the Hazad succession manifest sustained regression initially, followed by transgression during the Middle Eocene time.

\section{Acknowledgements}

The authors are immensely grateful to Shri A K Dwivedi, Director (Exploration), ONGC for permission to publish the paper. Thanks are due to Dr. D N Singh, ED-HoI, KDMIPE, ONGC for extending the support and facilities at KDMIPE. The authors thank three anonymous reviewers for thoroughly reviewing the manuscript and suggesting constructive comments. The help rendered by functionaries of Sedimentology Division, Geology Group, KDMIPE, ONGC especially Dr. Snehasis Chakrabarty, Suptdg. Geologist and RGL, Vadodara, ONGC is also gratefully acknowledged.

\section{References}

Abbasi N A, Pandey A N, Upadhaya H and Nagasudha V 1992 Lithofacies, depositional environments and reservoir characteristics of Hazad sands in the eastern flank of Broach depression; Unpublished report, ONGC, RGL, WRBC, Baroda.

Allen J R L 1981 Lower cretaceous tides revealed by crossbedding with mud drapes; Nature 289 579-581.

Archer A W, Fredman H R and Kvale E P 1994 Comparison of drier to wetter interval estuarine roof facies in the eastern and western interior coal basin, USA; Palaeogeogr. Palaeoclimat. Palaeoeco. 106 171-185.

Archer A W, Kuecher G J and Kvale E P 1995 The role of tidal velocity asymmetricities in the deposition of silty tidal rhythmites (Carboniferous Eastern Interior Coal Basin, USA); J. Sediment. Res. 65(A) 408-416.

Aswal H S, Das K K, Yadava U N, Nayak K K, Prathimon P T and Rana P B 2013 Lithobiostratigraphic correlation and paleoenvironment of Hazad Pays in eastern part of Jambusar-Broach block, Cambay Basin; 10th Biennial
International Conference and Exposition, Kochi, 170, $1-11$.

Bhattacharya B and Banerjee P P 2015 Record of Permian Tethyan transgression in eastern India: A reappraisal of the Barren Measures Formation, West Bokaro Coal field; Mar. Petrol. Geol. 67 170-179.

Bhattacharya B, Bandyopadhyay S, Mahapatra S and Banerjee S 2012 Record of tide-wave influence on the coalbearing Permian Barakar Formation, Raniganj Basin, India; Sedim. Geol. 267-268 25-35.

Bhattacharya B and Jha S 2014 Late Cretaceous diurnal tidal system: A study from Nimar Sandstone, Bagh Group, Narmada Valley, Central India; Curr. Sci. 107(6) 1032-1037.

Bhattacharya H N and Bhattacharya B 2006 A PermoCarboniferous tide-storm interactive system: Talchir Formation, Raniganj Basin, India; J. Asian Earth Sci. 27 303-311.

Bhattacharya H N, Bhattacharya B, Pal S and Roy A 2015 Late Archaean tidalites from western margin of Chitradurga greenstone belt, southern India; Precamb. Res. 257 109-113.

Biswas S K 1982 Rift basins in western margins of India and their hydrocarbon prospects with special reference of Kutch Basin; AAPG Bull. 135 307-327.

Boersma J R 1969 Internal structure of some tidal megaripples on shoal in the Westerschelde estuary, the Netherlands: Report of a preliminary investigation; Geologie en Mijnbouw 48 409-414.

Boersma J R and Terwindt J H J 1981 Neap-spring tide sequences of intertidal shoal deposits in a mesotidal estuary; Sedimentology 28 151-170.

Choi K and Kim D H 2016 Morphologic and hydrodynamic controls on the occurrence of tidal bundles in an opencoast macrotidal environment, northern Gyeonggi Bay, west coast of Korea; Sedim. Geol. 339 68-82.

Coughenour C L, Archer A W and Lacovara K J 2009 Tides, tidalites, and secular changes in the Earth-Moon system; Earth Sci. Rev. 97 59-79.

Dalrymple R W and Choi K 2007 Morphologic and facies trends through the fluvial-marine transition in tidedominated depositional system: A schematic for environmental and sequence stratigraphic interpretation; Earth Sci. Rev. 81 135-174.

Dalrymple R W, Makins Y and Zaitlin B A 1991 Temporal and spatial pattern of rhythmite deposition on mudflat in the macrotidal Cobequid Salmon River Estuary, Bay of Fundy, Canada; In: Clastic Tidal Sedimentology (eds) Smith D G, Reinson G F, Zaitline B A and Rahmani R A; Canad. Soc. Petrol. Geol. Memoir 16 137-160.

Eriksson K A and Simpson E L 2000 Quantifying the oldest tidal record: The 3.2 Ga Moodies Group, Barberton Greenstone Belt, South Africa; Geology 28 831-834.

Fan D D 2013 Classifications, sedimentary features and facies associations of tidal flats; J. Palaeogeogr. 2(1) $66-80$.

Greb S F and Archer A W 1995 Rhythmite sedimentation in a mixed tide and wave deposit, Hazel Patch Sandstone (Pennsylvanian) Eastern Kentucky Coalfield; J. Sedim. Res. B65 96-106. 
Greb S F, Archer A W and Deboer D G 2011 Apogean-perigean signals encoded intertidal flats at the fluvio-estuarine transition of Glacier Creek, Turnagain Arm, Alaska: Implications for ancient tidal rhythmites; Sedimentology 58 1434-1452.

Klein G de V 1970 A sedimentary model for determining paleotidal range; Geol. Soc. Am. Bull. 82 2585-2592.

Klein G de V 1998 Clastic tidalites - a partial retrospective view; In: Tidalites: processes and products (eds) Alexander C R, Davis R A Jr and Henry V J, SEPM Spec. Publ. $615-14$.

Kundu J, Kar S, Prakash A and Prasad B 1996 Basement Configuration and Distribution of depocenters of Cambay Basin; Unpublished report, ONGC.

Kvale E P 2006 The origin of neap-spring tidal cycles; Mar. Geol. 235 5-18.

Kvale E P 2012 Tidal constituents of modern and ancient tidal rhythmites: Criteria for recognition and analyses; In: Principles of Tidal Sedimentology (eds) Davis Jr R A and Dalrymple R W, Springer, pp. 1-16.

Kvale E P and Matarlerz M 1998 Evidence of ancient freshwater tidal deposits; In: Tidalites: Processes and Products (eds) Alexander C R, Davies R A and Henry V J; Soc. Econ. Palaeontol. Mineral Spec. Publ. 51 191-207.

Mazumder R 2004 Implications of lunar orbital periodicity from the Chaibasa tidal rhythmite (India) of late Palaeoproterozoic age; Geology 32 841-844.

Mazumder R and Arima M 2005 Tidal rhythmites and their implications; Earth Sci. Rev. 69 79-95.

Miall A D 1980 Cyclicity and the facies model concept in fluvial deposits; Bull. Can. Petrol. Geol. 14 337-381.

Mohan M, Bhattacharya S K, Sharma D C, Chowadhury C L and Shanmukhappa 1990 Environmental reconstruction and depositional modeling of Hazad Pay sands in Gandhar Field; Unpublished report, ONGC.
Nio S D, Siegenthaler C and Yang C S 1983 Megraripple cross-bedding as a tool for the reconstruction of the paleo-hydraulics in a Holocene subtidal environment, SW Netherlands; Geologie en Mijnbouw 62 499-510.

Nortan I O and Sclater J G 1979 A model for the evolution of the Indian Ocean break up of Gondwanaland; J. Geophys. Res. 84(B12) 6803-6830.

Pande A N, Bhattacharya S K, Chaudhury C L, Upadhyay H and Sharma D C 1989 Environmental reconstruction and depositional modelling of the Hazad pay sand in Gandhar field part II; Unpublished report, ONGC.

Parakh A K, Sinha D K, Ahmed A, Brahma K C, Prusty S K, Hussaini S and Shridhar K N 2013 Depositional model and facies distribution of Hazad sands, Narmada Block and integration with Broach Block, Cambay Basin; Unpublished report, ONGC, 58p.

Reading H 1996 Sedimentary Environments: Processes, Facies and Stratigraphy; 3rd edn, Wiley Blackwell, 704p.

Reineck H E 1972 Tidal flats; SEPM Spec. Publ. 16 146149.

Reineck H E and Singh I B 1980 Depositional Sedimentary Environments; Springer-Verlag, Berlin 549p.

Saha S, Burley S D, Banerjee S and Saraswati P K 2016 The morphology and evolution of tidal sand bodies in the macrotidal Gulf of Khambhat, Western India; Mar. Petrol. Geol. 77 1-17.

Visser M J 1980 Neap Spring cycles reflected in Holocene subtidal large-scale bed form deposits, a preliminary note; Geology 8 543-546.

Walker R G 1984 Facies sequences and facies models; Geol. Assoc. Can. 317.

Williams G E 1989 Late Precambrian tidal rhythmites in South Australia and the history of the earth rotation; J. Geol. Soc. London 146 97-111. 